\title{
Pilihan rasional ataukah pilihan yang terikat secara sosial? Studi kasus pengambilan keputusan pada remaja perempuan yang terlibat prostitusi
}

\author{
Santy Yanuar Pranawati*, Adriana Soekandar Ginanjar, \& Rudolf Woodrow \\ Matindas \\ Fakultas Psikologi, Universitas Indonesia, Depok, Jawa Barat
}

\begin{abstract}
Abstrak
Walau telah banyak penelitian yang membahas mengenai berbagai faktor dibalik keputusan remaja terlibat dalam prostitusi, tetapi masih sedikit yang menjelaskan rangkaian proses yang terjadi. Penelitian studi kasus ini dilakukan untuk memahami secara mendalam tentang proses pengambilan keputusan remaja perempuan yang terlibat dalam prostitusi tanpa adanya ancaman atau tekanan dari orang lain. Dalam menjelaskan proses yang terjadi, disoroti peranan rasionalitas terbatas pada remaja. Metode pengumpulan data yang digunakan adalah wawancara mendalam dan observasi non partisipan. Wawancara dilakukan terhadap 8 (delapan) partisipan yang terlibat prostitusi sejak sebelum berusia 18 tahun. Hasil penelitian menunjukkan bahwa proses pengambilan keputusan pada remaja perempuan untuk terlibat prostitusi terdiri dari tujuh tahap, yaitu: (1) mengalami permasalahan di dalam keluarga; (2) mencari dukungan sosial dari teman; (3) terpapar kenakalan remaja; (4) kebutuhan uang; (5) terpapar dunia prostitusi; (6) terlibat prostitusi; dan (7) keinginan dan usaha untuk keluar dari prostitusi.
\end{abstract}

Kata kunci: proses pengambilan keputusan, rasionalitas terbatas, prostitusi, pengalaman hidup, studi kasus

\begin{abstract}
Although there have been many studies that discuss the various factors behind the adolescents' decision to involve in prostitution, there is visibly little explanation for the series of processes that occur in previous literature. This case study was conducted to investigate the decision-making processes of female adolescents' who were involved in prostitution without any threats or pressure from others. In explaining the process that occurred, this paper highlighted the role of bounded rationality among adolescents. We conducted in-depth interviews and non-participant observation to collect the data. The participants of this study were eight girls (17 to 24 years old) who had been engaged in prostitution before the age of 18. The findings suggest there are seven phases on the decision-making process to engage in prostitution, namely (1) family disharmony; (2) looked for social support from peers; (3) exposed to juvenile delinquency; (4) need for money; (5) exposed to prostitution; (6) entered the world of prostitution; and (7) the eagerness and tried to get out from prostitution.
\end{abstract}

Keywords: decision-making process, bounded rationality, prostitution, life experience, case study

\section{Pendahuluan}

Keterlibatan anak dan remaja ke dalam prostitusi sudah lama terjadi, bahkan saat ini kasus perdagangan manusia untuk tujuan eksploitasi seksual anak telah mencapai $54 \%$ dari seluruh jumlah kasus perdagangan manusia (UNODC, 2016). Penelitian terkini menunjukkan bahwa anak usia 12 tahun sudah terlibat prostitusi dengan berbagai alasan, misalnya eksploitasi oleh organisasi kri- minal, terjerumus karena teman sebaya, pemenuhan gaya hidup modern, juga adanya fasilitas komunikasi yang semakin berkembang sehingga memudahkan transaksi terutama di ranah dunia maya (Cahya, 2015; Suprapto \& Martujdi, 2013).

Dalam konteks perempuan dewasa, kekerasan domestik, tuntutan kebutuhan pribadi atau keluarga dilihat sebagai faktor utama mengapa perempuan menjadi pekerja seks komersial, sehingga keputusan untuk menjadi pekerja seks 
tetap dilihat sebagai sebuah pilihan yang rasional sebagai alternatif sumber penghasilan (Fathona, 2016; Harsanti \& Verasari, 2013; Peng, 2005). Sedangkan dalam konteks perempuan remaja dan anak, ancaman pihak lain memang bukan faktor pendorong utama, tetapi terdapat beberapa faktor yang membuat remaja rentan untuk terlibat dalam prostitusi (Suhardjo \& Irwanto, 2018).

Berbagai penelitian terdahulu lebih banyak mengungkap faktor-faktor penyebab seseorang terlibat dalam prostitusi, seperti pengalaman yang menyakitkan atau rasa kehilangan yang tidak terduga, kondisi keluarga yang tidak harmonis, kekerasan seksual, gaya hidup, serta perilaku kenakalan remaja (Jonsson, Svedin, \& Hyden, 2014; Lutya, 2010; Wills, Gibbons, Gerrard, Murry, \& Brody, 2003; Wolak, 2009). Selain itu juga terdapat beberapa faktor risiko, seperti keberadaan orang tua tunggal, hubungan antara orang tua dan anak, serta maltreatment pada anak (McNeal \& Walker, 2016; Wilson \& Widom, 2008; Zeglin, 2014).

\section{Pengambilan keputusan dengan rasionalitas yang terbatas}

Pengambilan keputusan muncul ketika seseorang ingin memilih suatu tindakan terbaik dari berbagai pilihan, melakukan penetapan tujuan, menemukan dan merancang program yang sesuai, serta mengevaluasi dan memilih berbagai alternatif tindakan (Jain \& Lim, 2010; Simon \& Associates, 1986). Sedangkan rasionalitas adalah kriteria yang digunakan dalam keputusan atau sebagai prinsip yang digunakan untuk menjelaskan mengenai proses pengambilan keputusan (Barros, 2010).

Penelitian terdahulu mengenai tahapan atau proses pengambilan keputusan pada remaja telah banyak dilakukan (Campitelli \& Gobet, 2010; Commons, 2007; Dezfouli \& Balleine, 2013; Fischhoff, 2012; Malakooti, 2012). Salah satu contoh ialah ketika remaja menentukan perguruan tinggi yang akan dipilih (Jung, 2013) atau ketika remaja memilih aktivitas olahraga tertentu (Eraslan \& Caliskan, 2014). Hasil-hasil penelitian tersebut tidak selalu sesuai untuk menjelaskan pengambilan keputusan remaja pada berbagai kondisi yang menyebabkan mereka mengambil keputusan yang kurang tepat serta berisiko, dalam konteks penelitian ini adalah keterlibatannya ke dalam praktik prostitusi. Beberapa hal yang berpengaruh terhadap pengambilan keputusan dengan rasionalitas terbatas adalah keterbatasan fungsi kognisi dan pengetahuan, pengalaman, serta persepsi (Barros, 2010; Felin, Koenderink, \& Krueger, 2017; McFall, 2015). Lebih lanjut, Augier dan March (2001) juga menyatakan bahwa semua manusia dan proses mental yang dimiliki memiliki keterbatasan dalam melakukan pemrosesan informasi.

\section{Keterbatasan rasional pada remaja prostitusi}

Masa remaja merupakan periode yang rentan serta memiliki karakteristik rasa ingin tahu yang tinggi. Maka dari itu, terkadang remaja mengambil keputusan yang mengarah kepada tingkah laku berisiko, seperti terlibat dalam tindakan kejahatan, mengonsumsi minuman beralkohol, atau melakukan perilaku agresif dan kekerasan (Hansen, dkk., 2014; Shulman \& Cauffman, 2014; Terav \& Keltikangas, 1998).

Penelitian sebelumnya lebih banyak fokus pada kategori perilaku yang berisiko pada remaja, bukan pada proses pengambilan keputusan mereka. Keputusan remaja untuk terlibat perilaku berisiko dipengaruhi oleh beberapa komponen, seperti nilai-nilai yang diyakini, cara remaja merespon persoalan yang dihadapi, pembelajaran pada aspek afeksi dan sosial ketika berinteraksi dengan teman sebaya, faktor biologis, serta faktor lingkungan termasuk keluarga dan tempat tinggal (Blakemore \& Robins, 2012; Crone \& Dahl, 2012; Jessor \& Turbin, 2014; Wolff, 2012). Lingkungan teman juga berpengaruh terhadap perilaku berisiko pada remaja, seperti melakukan hubungan seksual dan mengonsumsi minuman beralkohol (Jeon \& Goodson, 2015).

Pengambilan keputusan yang dilakukan oleh remaja memiliki karakteristik berorientasi jangka pendek, lebih mementingkan hasil, dan bukan untuk memecahkan masalah yang dihadapinya, sehingga keputusan-keputusan yang diambil justru membawa remaja masuk ke dalam permasalahan yang lebih dalam (Blakemore \& Robins, 2012; Crone \& Dahl, 2012; Hansen, dkk., 2014; Shulman \& Cauffman, 2014; Terav \& Keltikangas, 1998; Wolff, 2012). Periode usia remaja juga menjadi salah satu karakter bagi individu untuk bertindak secara reaktif dan kurang kontrol (Andrews-Hanna, dkk., 2011). Maka karenanya, keputusan-keputusan yang diambil cenderung bersifat impulsif tanpa memikirkan dampak di kemudian hari, termasuk pada akhirnya terlibat ke dalam tingkah laku berisiko (Gardner \& Steinberg, 2005).

Pengalaman hidup yang dialami oleh seseorang juga dapat membatasi kemampuannya dalam berpikir rasional serta dapat menghalangi untuk mengambil keputusan yang ideal (McFall, 2015). Pada konteks remaja yang terlibat prostitusi, pengalaman dan kondisi hidup yang membatasi berpikir rasionalnya, antara lain adanya tuntutan kebutuhan, menjadi korban kekerasan, pengaruh lingkungan, gaya hidup modern, atau bahkan menjadi korban eksploitasi oleh organisasi kriminal (Cahya, 2015, Fathona, 2016; 
Harsanti \& Verasari, 2013; Peng, 2005; Suprapto \& Martujdi, 2013).

Penelitian terdahulu juga lebih banyak fokus pada remaja terlibat prostitusi yang berada di bawah ancaman atau tekanan pihak lain. Sedangkan pada kenyataannya, terdapat beberapa remaja yang terlibat ke dalam prostitusi bukan atas ancaman atau paksaan pihak lain. Kelompok remaja ini masih memiliki pilihan untuk tidak terlibat ke dalam prostitusi. Oleh karena itu, peneliti berpendapat bahwa penting untuk dilakukan penelitian ini, yaitu mengeksplorasi tentang bagaimana proses keputusan seorang remaja terlibat ke dalam prostitusi tanpa adanya ancaman atau tekanan dari pihak lain.

Beberapa penelitian sebelumnya menyebutkan bahwa keputusan seseorang untuk terlibat prostitusi merupakan keputusan yang rasional (Calhoun \& Weaver, 1996; Rosen \& Venkatesh, 2008). Sedangkan penelitian ini memiliki pendapat bahwa seorang remaja perempuan yang "memutuskan" untuk terlibat prostitusi memiliki berbagai kondisi yang menyebabkan keterbatasan dalam berpikir rasional, sehingga pada akhirnya terlibat ke dalam prostitusi. Penelitianpenelitian sebelumnya juga lebih fokus pada kategorisasi faktor-faktor penyebab prostitusi, sedangkan di sini peneliti memiliki pandangan bahwa perlu adanya kajian yang menjelaskan mengenai proses keterlibatan remaja ke dalam dunia prostitusi.

Di samping itu, sejauh pengetahuan peneliti, masih belum ditemukan literatur yang membahas proses atau dinamika keterlibatan remaja dalam prostitusi yang komprehensif serta berdasar bukti empiris. Berbagai pengalaman hidup dan kondisi psikologis yang dimiliki menyebabkan remaja rentan untuk memutuskan terlibat ke dalam praktik prostitusi. Oleh karena itu, penelitian ini mencoba untuk menjelaskan tahapan proses pengambilan keputusan remaja hingga akhirnya masuk ke dalam dunia prostitusi dengan memperhatikan pengalaman hidup dan kondisi psikologis yang dimilikinya.

\section{Metode Penelitian}

\section{Desain dan partisipan penelitian}

Penelitian kualitatif ini menggunakan pendekatan studi kasus, yang memberikan gambaran mendalam dan holistik mengenai kasus yang unik, khusus, atau menarik (Yin, 2014). Kriteria partisipan penelitian adalah (1) remaja atau dewasa muda perempuan berusia 17-24 tahun; (2) terlibat prostitusi sebelum usia 18 tahun; (3) memutuskan untuk masuk ke dunia prostitusi tanpa tekanan atau ancaman orang lain. Partisipan penelitian ini adalah delapan remaja perempuan yang terlibat dalam prostitusi antara usia 14-17 tahun. Identitas partisipan dapat dilihat secara rinci pada Tabel 1. Demi menjaga kerahasiaan identitas partisipan, peneliti mencantumkan nama samaran.

Tabel 1.

Identitas Partisipan Penelitian

\begin{tabular}{|c|c|c|c|c|c|}
\hline $\begin{array}{l}\text { Partisipan } \\
\text { (samaran) }\end{array}$ & Usia & Pendidikan & $\begin{array}{l}\text { Usia terlibat } \\
\text { prostitusi }\end{array}$ & $\begin{array}{l}\text { Jumlah usaha keluar } \\
\text { dari Prostitusi }\end{array}$ & Tempat tinggal \\
\hline Alda & 24 tahun & SMK kelas 2 & 16 tahun & 3 kali & Kos sendiri \\
\hline Bella & 23 tahun & Tamat SMA & 17 tahun & 1 kali & Kos sendiri \\
\hline Cherry & 23 tahun & SMP kelas 2 & 14 tahun & 1 kali & Tinggal dengan suami \\
\hline Cimoy & 22 tahun & SMK kelas 1 & 14 tahun & 3 kali & Kos sendiri \\
\hline Devi & 23 tahun & Kejar paket $\mathrm{C}$ & 14 tahun & 1 kali & Tinggal dengan orang tua \\
\hline Eva & 18 tahun & SMA kelas 2 & 16 tahun & Tidak pernah & Tinggal dengan orang tua \\
\hline Nadya & 17 tahun & SMA kelas 2 & 15 tahun & Tidak pernah & Kos sendiri \\
\hline Vera & 20 tahun & Tamat SMA & 15 tahun & 2 kali & Kos sendiri \\
\hline
\end{tabular}

\section{Metode pengumpulan data}

Penelitian ini telah memenuhi kriteria dari Tim Kaji Etik Fakultas Psikologi, Universitas Indonesia (Nomor: 506/FPsi. Komite Etik/PDP. 04.00/2016). Dalam pengumpulan data, peneliti dibantu oleh Yayasan Bahtera Bandung yang bergerak dalam perlindungan anak, termasuk remaja yang terlibat prostitusi. Hal ini karena keberadaan para remaja tersebut tersembunyi, sehingga sulit bagi peneliti untuk menemukan partisipan tanpa bantuan pihak lain. Proses wawancara mendalam dilakukan oleh peneliti pertama, yang merupakan psikolog klinis dan telah memiliki pengalaman dalam menangani kasuskasus remaja berisiko (seperti: kenakalan remaja dan remaja yang terlibat prostitusi). Data-data yang dikumpulkan pada penelitian ini juga digunakan pada artikel jurnal lain, tetapi topik yang ditulis berbeda dari topik yang diangkat pada artikel ini. 
Sebelum dilakukan wawancara, peneliti menjelaskan tujuan penelitian dan menanyakan kesediaan remaja untuk menjadi partisipan penelitian. Peneliti memberikan lembar informed consent untuk ditandatangani. Para partisipan tidak menerima imbalan untuk keikutsertaan mereka dalam penelitian, namun mendapat uang untuk mengganti biaya transportasi. Pada masingmasing partisipan dilakukan wawancara mendalam antara satu hingga tiga kali pertemuan, dengan total durasi antara 90-150 menit.

\section{Teknik analisis data}

Analisis data yang dilakukan menggunakan pendekatan konten analisis (Cavanagh, 1997; Hsieh \& Shannon, 2005). Dengan pendekatan ini, teori dan temuan penelitian terdahulu menjadi pedoman bagi peneliti untuk membuat kodifikasi berdasarkan hasil wawancara. Kami juga mengeksplorasi tema atau kategori lain apabila adanya jawaban di luar teori atau temuan sebelumnya. Proses pengodean dimulai dengan melakukan pengodean terbuka. Kode terbuka ini dilakukan untuk menentukan pengalaman hidup yang dialami oleh masing-masing partisipan. Setelah itu, peneliti mencoba untuk mencari tema-tema yang muncul dari transkrip untuk ditetapkan menjadi tema-tema yang akan menjadi pembahasan pada tahap akhir proses analisis (Creswell, 2016). Peneliti menemukan tema-tema yang berkaitan dengan pengalaman yang membuat remaja memiliki keterbatasan dalam berpikir rasional, lalu akhirnya rentan untuk terlibat ke dalam prostitusi.

\section{Hasil Penelitian}

Pertanyaan utama untuk mengungkap proses pengambilan keputusan remaja perempuan terlibat prostitusi adalah "Apakah Anda bisa menceritakan tentang bagaimana awal mula terlibat ke dalam prostitusi?". Dari pertanyaan ini, muncul beberapa kondisi yang dialami oleh remaja, termasuk pengalaman hidupnya di lingkungan keluarga, teman, dan pengalaman yang berpengaruh terhadap kondisi psikologisnya. Berikut paparan mengenai tahapan proses pengambilan keputusan remaja, di mana ringkasan proses tersebut dapat dilihat pada Gambar 1. Verbatim para partisipan terkait dengan tahapan pengambilan keputusan dapat dilihat pada Lampiran A.

\section{1) Mengalami permasalahan di dalam keluarga}

Beberapa kondisi menyebabkan remaja merasa tidak terpenuhi kebutuhan afeksinya, seperti perceraian orang tua dan perselingkuhan ayah yang berdampak terhadap kedekatan antara orang tua dan anak. Selain hubungan antara ayah dan ibu yang tidak harmonis, permasalahan lain ialah tidak adanya kedekatan antara remaja dengan saudara kandungnya. Perasaan diperlakukan berbeda dari kakak atau adiknya menimbulkan perasaan iri.

Sebagai wujud protes, remaja menampilkan perilaku-perilaku seperti memusuhi saudara, melawan orang tua, bahkan melanggar peraturan di dalam rumah-seperti pulang larut malam dan/atau pergi keluar rumah tanpa izin. Kebutuhan-kebutuhan fisik dan materi telah tercukupi dengan baik, tetapi hal tersebut tidak cukup untuk membangun keintiman emosional di antara anggota keluarga. Rasa kesepian di dalam rumah membuat remaja pada akhirnya memilih untuk lebih banyak menghabiskan waktu bersama dengan orang lain, misalnya lebih banyak menghabiskan waktu dan tidur di rumah saudara atau teman.

\section{2) Mencari dukungan sosial dari lingkungan teman}

Situasi tidak nyaman dan tidak adanya tempat untuk berbagi ketika sedang menghadapi masalah di dalam rumah membuat remaja berusaha mencari ketenangan di tempat lain. Lingkungan teman akhirnya menjadi tempat yang paling nyaman dan menjadi sumber kebahagiaan bagi remaja, serta dapat berbagi cerita untuk menyampaikan permasalahan yang dihadapi. Selain penerimaan dari anggota kelompok, juga adanya rasa setia kawan yang tinggi. Misalnya, apabila seseorang mengalami kesulitan, maka anggota lain akan membantu menyelesai masalahnya, termasuk saat mengalami kesulitan untuk makan dan tempat tinggal.

\section{3) Terpapar dan terlibat dalam perilaku kenakalan} remaja

Remaja menemukan lingkungan teman yang menyediakan berbagai kebutuhan, khususnya sebagai tempat untuk memperoleh kesenangan, kenyamanan, termasuk juga perlindungan. Pada situasi ini, remaja seakan memperoleh "keluarga baru" sehingga remaja lebih sering meninggalkan rumah dan tinggal bersama dengan teman-temannya. Namun di sisi lain, lingkungan teman juga dapat membawa remaja terlibat ke dalam tingkah laku berisiko, seperti merokok, mengonsumsi minuman beralkohol dan narkoba, bergabung dengan geng motor, perilaku seks bebas, pergaulan di dunia malam, gaya hidup mewah, dan lain sebagainya.

4) Meninggalkan rumah dan dituntut untuk hidup mandiri: uang sebagai penyedia biaya hidup dan memenuhi "gaya hidup" 
Meninggalkan rumah menuntut remaja untuk dapat hidup secara mandiri, yang berarti remaja harus memenuhi segala kebutuhannya sendiri karena meninggalkan rumah dalam waktu yang lama atau bahkan memutuskan untuk hidup berpisah dari keluarga. Kondisi ini mengharuskan remaja untuk bisa membiayai kebutuhan tempat tinggal dan makanan, termasuk kebutuhan untuk rokok, minuman beralkohol, bahkan obat-obatan terlarang. Selain itu, remaja perempuan juga memiliki kebutuhan untuk menunjang penampilan dan "gaya hidup" seperti membeli pakaian, sepatu, tas, make-up, perawatan tubuh, dan aksesori lain yang membutuhkan biaya yang tidak sedikit.

\section{5) Terpapar dunia prostitusi}

Kelompok teman merupakan "pintu gerbang" bagi remaja untuk mengenal dunia prostitusi. Semula remaja tidak mengetahui bahwa teman-temannya terlibat prostitusi, bahkan tidak mengetahui bahwa teman-temannya memiliki uang atau pendapatan dari aktivitasnya di dunia prostitusi. Namun, pada akhirnya, remaja mengetahui bahwa uang yang dimiliki oleh teman-temannya selama ini adalah hasil dari bekerja menjadi pemandu lagu atau menerima booking order (berhubungan seksual dengan tamu). Teman-temannya memberikan informasi bahwa menjadi pekerja malam akan memiliki penghasilan yang sangat cukup, termasuk dapat mencukupi kebutuhan untuk mempercantik diri.

Gambar 1.

Tahapan proses pengambilan keputusan remaja

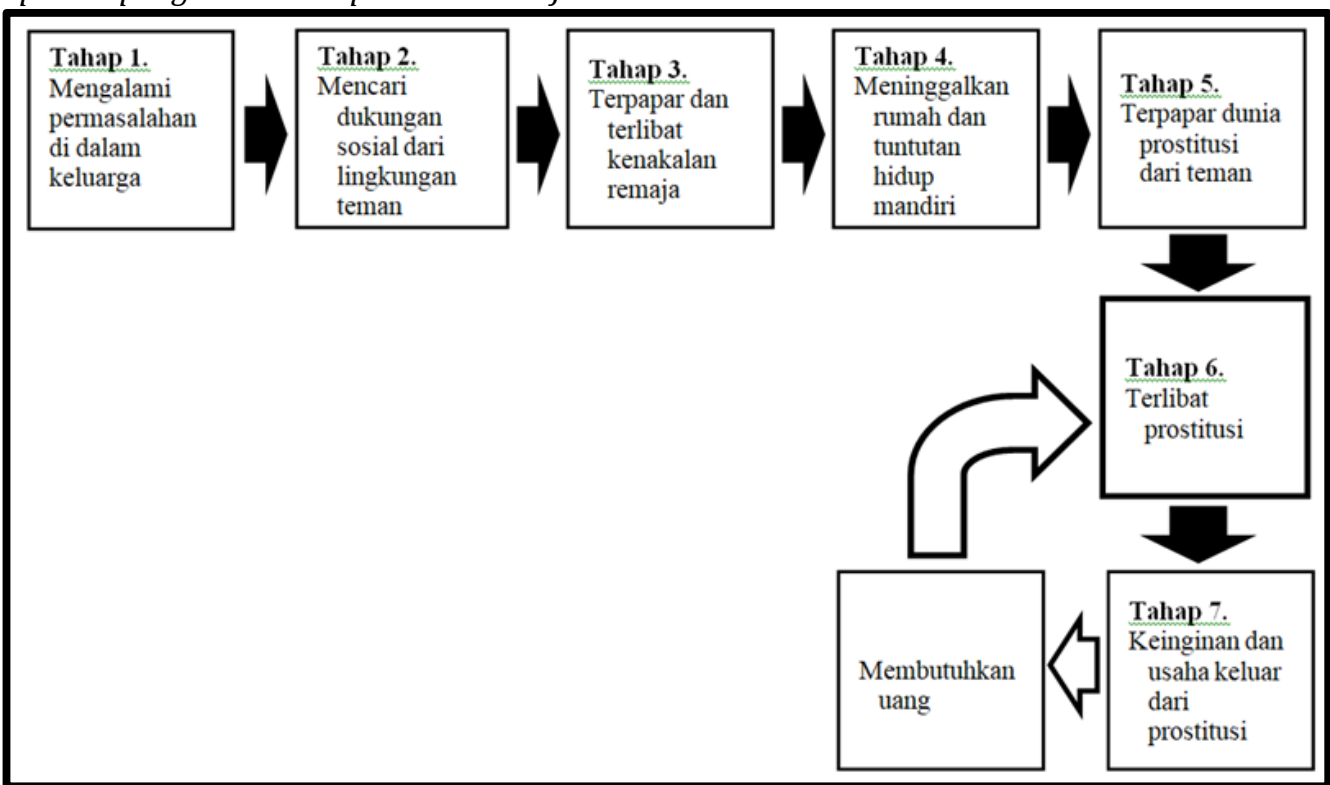

Catatan:

*Tanda panah hitam: rangkaian tahapan proses pengambilan keputusan;

*Tanda panah putih: rangkaian proses yang berulang.

\section{6) Terlibat prostitusi}

Remaja mengenal dan mengetahui aktivitas prostitusi dari teman-temannya. Persuasi yang kuat dari teman, kebutuhan ekonomi, dan karakteristik impulsif membuat remaja menetapkan pilihannya untuk masuk ke dalam prostitusi. Kondisi membutuhkan uang membuat remaja terbujuk untuk menerima tawaran teman terlibat ke dalam prostitusi. Namun, di samping kebutuhan akan uang, ternyata ada kondisi lain yang memperkuat kerentanan remaja untuk terlibat prostitusi, yaitu perilaku seks bebas. Walaupun hubungan seksual yang dilakukan dengan kekasih berdasarkan atas rasa suka sama suka, tetapi kondisi tidak perawan memberikan dampak terhadap kondisi psikologisnya. Selain rasa sesal, remaja perempuan juga memiliki permasalahan terkait dengan harga dirinya.

7) Menyesali perbuatannya: ingin dan berusaha keluar dari prostitusi

Keterlibatan di dalam prostitusi membuat remaja mampu untuk bertahan hidup dan memenuhi segala kebutuhannya. Memang sebagian remaja partisipan telah berusaha untuk keluar dari lingkaran tersebut, tetapi ada dua remaja yang menyatakan belum pernah berusaha untuk keluar. Walaupun demikian, bukan berarti mereka ingin tetap selamanya di dalam lingkungan prostitusi. 
Situasi menjadi tidak mudah ketika para remaja memiliki keinginan untuk keluar dan menjalani kehidupan "normal". Di satu sisi, para remaja membutuhkan biaya untuk hidup sebab secara finansial mereka telah hidup mandiri dan tidak bergantung kepada orang tua, akan tetapi di sisi lain mereka mengalami konflik batin karena menjalani profesi yang dilarang secara agama, hukum, dan norma sosial. Terlebih, bagi remaja yang memiliki anak, mereka merasa bahwa perlu mencari uang dengan cara yang halal.

Ada perasaan gelisah ketika harus menghidupi anak dengan uang hasil dari dunia prostitusi. Namun, usaha-usaha yang dilakukan belum berhasil dan belum dapat membantu remaja untuk benar-benar keluar dari lingkungan tersebut.

\section{Diskusi}

Proses pengambilan keputusan seorang remaja perempuan untuk terlibat atau tidak ke dalam prostitusi merupakan proses yang panjang dan kompleks. Remaja harus melewati beberapa titik pengambilan keputusan penting, termasuk ketika memutuskan untuk mencari solusi atas kebutuhan kenyamanan yang tidak diperoleh di dalam rumah. Sifat remaja yang impulsif dan terbatas secara rasional menyebabkan keputusan-keputusan penting tidak didahului dengan pemahaman yang tepat tentang kondisi-kondisi yang ada, juga tidak melakukan survei atau pertimbangan terhadap alternatif-alternatif pemecahan masalah, sehingga hasil keputusan tidak direfleksikan kembali. Di sini remaja cenderung hanya fokus pada masalah-masalah yang ada dihadapannya, mencari cara pemecahan masalah terbatas pada kelompok teman sebaya, lalu akhirnya menghadapi masalah-masalah baru yang lebih kompleks akibat keputusan yang tidak tepat sebelumnya.

Rangkaian proses ini membuat remaja semakin rentan untuk terlibat ke dalam prostitusi. Berbagai kondisi berpengaruh terhadap pengambilan keputusan mulai dari awal yaitu iklim keluarga, pengaruh kelompok sebaya, kenakalan remaja (termasuk perilaku seks bebas), hidup berpisah dari orang tua, tuntutan mendapatkan uang untuk memenuhi kebutuhannya, hingga akhirnya terlibat ke dalam prostitusi.

Ketidakharmonisan keluarga, pengaruh teman sebaya, dan keterlibatan dalam kenakalan remaja (seperti: konsumsi alkohol dan narkoba, bergabung dengan geng motor, perilaku seks bebas) menyebabkan remaja memiliki keterbatasan dalam berpikir rasional. Hasil ini sejalan dengan penelitian terdahulu yang menunjukkan bahwa faktor-faktor tersebut menyebabkan remaja rentan terlibat prostitusi (Jonsson, Svedin, \& Hyden, 2014; McNeal \& Walker, 2016; Wilson \& Widom, 2008; Zeglin, 2014).
Kondisi keluarga yang tidak nyaman menjadi salah satu hal yang berkontribusi terhadap tingkah laku berisiko pada remaja (McGue, Elkins, Walden, \& Iacono, 2005). Ketidaknyamanan suasana di dalam rumah dapat menjadi salah satu alasan remaja meninggalkan rumah atau memilih untuk tinggal di luar rumahnya (Keijsers \& Poulin, 2013; Tucker, Edelen, Ellickson, \& Klein, 2011). Di sisi lain, keluarga merupakan faktor penting dalam mendukung perkembangan seorang remaja, termasuk juga mencegah remaja untuk terlibat dalam perilaku-perilaku yang berisiko tinggi seperti berhubungan dengan teman sebaya yang memiliki perilaku antisosial, terlibat kenakalan remaja, atau mencoba tentang hal yang berkaitan dengan seksualitas (Feinberg, Jones, Kan, \& Goslin, 2010; Gault-Sherman, 2012; Vanassche, Sodermans, Matthijs, \& Swicegood, 2014).

Remaja yang terpapar informasi dari teman-temannya terkait dengan tingkah laku berisiko pada akhirnya akan cenderung terbawa kepada perilaku kenakalan remaja seperti membolos dari sekolah, terlibat dalam geng motor, merokok, mengonsumsi alkohol dan zat adiktif lainnya, termasuk perilaku seks bebas. Hal ini sejalan dengan penelitian dari Jaccard, Blanton, dan Dodge (2005), dimana lingkungan teman sebaya juga dapat mendorong tingkah laku berisiko seperti mengonsumsi alkohol dan aktivitas seksual. Remaja terjebak dalam kesenangan dan kenikmatan sesaat yang hanya berorientasi "di sini dan saat ini", serta cenderung membentuk tujuan dan mengadopsi perilaku yang hanya mementingkan kepuasan sesaat (Henson, Carey, Carey, \& Maisto, 2006). Pada situasi ini, akhirnya remaja yang memiliki teman dengan tingkah laku berisiko menjadi kurang berminat terhadap kelompok teman yang justru memiliki kegiatan lebih positif (Thorlindsson \& Bernburg, 2006). Segala bentuk tingkah laku berisiko dan impulsif pada remaja sering disebabkan karena kegagalan dalam menilai dan mengambil keputusan. Walaupun remaja telah melakukan berbagai pertimbangan, tetapi pertimbangan yang dilakukan ternyata kurang tepat dan kemampuan penilaian seorang remaja masih tergolong lemah (Cooper, Wood, Orcutt, \& Albino 2003; Matzler, Uzelac, \& Bauer, 2014; Modecki, 2008).

Penelitian Zuckerman dan Kuhlman (2000) mengungkapkan bahwa seorang remaja dengan kepribadian yang impulsif dan pencari sensasi akan cenderung memiliki perilaku berisiko yang tinggi, baik perempuan ataupun laki-laki. Hubungan seksual aktif yang dilakukan oleh teman juga dapat mendorong remaja untuk terlibat dalam aktivitas seksual seperti yang dilakukan oleh teman-temannya tersebut (Chuang, Ennett, Bauman, \& Foshee, 2009; Cook, Buehler, \& Henson, 2009; Stanton, Pack, Cottrell, Harris, \& Burns, 2002). 
Keputusan remaja untuk memilih menghabiskan waktu lebih banyak dengan teman-temannya atau bahkan memilih untuk keluar dari rumah membuat perilaku seks bebas menjadi lebih berisiko, misalnya terlibat dalam perdagangan seksual (Kaestle, 2012).

Penelitian ini menunjukkan bahwa terdapat situasi yang membuat remaja semakin rentan untuk memutuskan terlibat dalam praktik prostitusi, yaitu keterlibatannya dalam perilaku seks bebas. Sebagian remaja menganggap bahwa hubungan seks bebas merupakan hubungan yang wajar untuk dilakukan, akan tetapi bagi sebagian remaja hubungan seks di usia dini dapat berpengaruh terhadap perilaku seks berisiko, berdampak terhadap kondisi psikologis, seperti gambaran diri yang negatif, perasaan depresi, dan ide untuk bunuh diri (Baams, Dubas, Overbeek, \& Van Aken, 2015; Heidmets, dkk, 2010; Kaplan, Jones, Olson, Yunzal-Butler, 2013; Vasilenko, Ram, \& Lefkowitz, 2011).

Selain itu, remaja merasa menjadi "tidak berharga" akibat perilaku seks bebas yang menyebabkan kehilangan keperawanannya (Haidt, 2012). Kondisi ini dapat terjadi antara lain karena nilai atau pesan moral terkait dengan arti "keperawanan" yang dimiliki oleh remaja. Ketika berada di lingkungan keluarga atau sekolah, remaja memperoleh pesan-pesan moral terkait seksualitas. Namun ketika mereka berada di lingkungan pergaulan, remaja mengamati konstruksi sosial baru, dimana perilaku seks bebas ternyata umum terjadi. Keterbatasan pengalaman dan kapasitas rasional membuat remaja beranggapan bahwa "norma" pergaulan yang bebas adalah standar normatif baru, sehingga ketika salah satu risiko terjadi maka remaja akan mengalami konflik batin atau disonansi kognitif yang menyebabkan merasa sangat tidak nyaman (Heidmets, dkk, 2010; Vasilenko, Ram, \& Lefkowitz, 2011). Selain itu, karena keterbatasan pengalaman dan kapasitas rasional, maka kondisi tidak perawanan menjadikan perempuan merasa "sah" untuk terlibat dalam prostitusi (Matswetu \& Bhana, 2018; Schlegel, 1991).

Dalam penelitian ini, prostitusi dipandang sebagai solusi terhadap permasalahan yang dialami. Namun, remaja sebenarnya menyadari bahwa keputusannya tersebut tidaklah benar. Walaupun terdapat dua partisipan yang belum mencoba untuk keluar dari prostitusi, tetapi mereka berdua juga menyatakan tidak ingin selamanya berada di lingkungan tersebut. Setelah kehidupan di dunia tersebut terus dijalani, mereka mengalami ketakutan bila aktivitas mereka diketahui oleh orang tua, muncul perasaan bersalah, berdosa, dan merasa tertekan (Sinacore, Jaghori, \& Rezazadeh, 2015). Oleh karena itu, remaja memikirkan bagaimana keluar dari dunia prostitusi, bahkan mencoba mencari pekerjaan yang dianggap "umum" oleh masyarakat. Namun hal ini juga tidak mudah, seseorang yang telanjur masuk ke dalam dunia prostitusi akan sulit untuk lepas atau keluar dari kondisi tersebut, sebab aktivitas seksual yang dilakukan dengan orang lain bertujuan untuk mendapatkan uang (Kangiwa, 2015; McNeal \& Walker, 2016; Sanders, O'Neill, Pitcher, 2017). Oleh karena itu, bagi seseorang yang sudah terlanjur berada di dalam dunia prostitusi, uang menjadi alasan yang kuat untuk tetap tinggal di dalamnya (Choi, 2011; Hunt \& Chamberland, 2006; Inciardi, 1995; Janet, 2002).

\section{Kesimpulan}

Dari paparan di atas, dapat disimpulkan bahwa kondisi yang membatasi remaja untuk berpikir rasional untuk menghasilkan keputusan yang ideal terhadap solusi dari masalahnya adalah karakteristik pengambilan keputusan pada tahapan usia remaja yang cenderung impulsif dan tidak memikirkan risiko jangka penjang. Hal ini membuat remaja terlibat dalam tingkah laku berisiko, termasuk akhirnya berada di lingkungan yang terpapar prostitusi. Selain itu, terdapat kondisi yang memperkuat keterbatasan remaja untuk berpikir rasional, yaitu kondisi "tidak perawan" yang merupakan akibat dari hubungan seks dengan pacar. Konstruksi sosial tentang pandangan keparawanan, membuat remaja merasa "kehilangan harga diri" yang akhirnya rentan untuk "memutuskan" terlibat prostitusi.

Kompleksitas kejadian yang dialami dalam hidup menyebabkan remaja rentan untuk memutuskan terlibat ke dalam prostitusi, sehingga memiliki proses atau tahapan pengambilan keputusan yang khusus. Selain itu, hasil penelitian ini juga dirasa penting karena remaja menjadi korban eksploitasi seksual bukan hanya adanya tekanan atau ancaman pihak lain, akan tetapi didasarkan pada kerentanan pada remaja sehingga "memutuskan" untuk terlibat atau tidak ke dalam praktik prostitusi.

\section{Keterbatasan Studi}

Ada beberapa hal yang dapat dicatat sebagai keterbatasan pada studi ini. Pertama, konteks partisipan dalam studi ini adalah remaja terlibat prostitusi bukan karena paksakan dan ancaman dari pihak lain. Oleh karena itu, paparan hasil dari studi ini tidak dapat digeneralisasikan pada kelompok korban eksploitasi seksual lainnya. Keterbatasan kedua, studi ini hanya dilakukan pada remaja perempuan, oleh karena itu penting bagi studi selanjutnya untuk melakukan pendalaman terhadap remaja laki-laki, yang mungkin memiliki dinamika pengambilan keputusan yang ber- 
beda. Ketiga, perspektif teori pada studi ini adalah teori pengambilan keputusan rasionalitas yang terbatas. Oleh karena itu, perlu paparan dari sudut pandang pendekatan teori pengambilan keputusan yang lain, misalnya pendekatan pemrosesan informasi atau pendekatan teori perilaku.

\section{Daftar Pustaka}

Andrews-Hanna, J., Seghete, K. L. M., Claus, E. D., Burgess, G. C., Ruzic, L., \& Banich, M. T. (2011). Cognitive control in adolescence: neural underpinnings and relation to selfreport behaviors. PLoS One, 6(6). https://doi.org/

10.1371/journal.pone.0021598

Augier, M., \& March, J. G. (2001). Remembering Herbert A. Simon (1916-2001). Public Administration Review, 61(4): 396-402. https://search.proquest.com /docview/19716 9742?accountid=17242.

Baams, L., Dubas, J. S., Overbeek, G., \& van Aken, M. A. G. (2015). Transitions in body and behavior: a meta-analytic study on the relationship between pubertal development and adolescent sexual behavior. Journal of Adolescent Health, $56(6)$,

586-598. https://doi.org/10.1016/j.jadohealth.201 4.11.019.

Barros, G. (2010). Herbert A. Simon and the concept of rationality: Bounderies and procedurs. Brazilian Journal of Political Economy, 30 (119): 455472. https://doi.org/10.1590/ S010131572010000300006.

Blakemore, S. J. \& Robbins, T. W. (2012). Decision-making in the adolescent brain. Nature Neuroscience 15(9): 1184-1191. https://doi.org/10.1038/nn.3177.

Campitelli, G., \& Gobet, F. (2010). Herbert Simon's decision-making approach: investigation of cognitive processes in experts. Review of General Psychology,14(4): 354-364. https://doi.org/10.1037/a0021256.

Cahya, K. D. (April 26, 2015). Pekerja seks di bawah umur di kalibata city hamil enam bulan. Diunduh dari: http://megapolitan.kompas.com/read

Calhoun, T. C., \& Weaver, G. (1996). Rational decision-making among male street prostitutes. Deviant Behavior, 17(2), 209227.

https://doi.org/10.1080/01639625.1996. 9968023

Cavanagh, S. (1997). Content analysis: concepts, methods and applications. Nurse
Researcher, 4(3), 5-16. https://doi.org/10.7748/nr.4.3.5.s2

Choi, S. Y. P. (2011). State control, female prostitution and HIV prevention in China. The China Quarterly 205: 96-114. https://doi.org/10.1017/S030574101000 1414.

Chuang, Y., Ennett, S. T., Bauman, K. E., \& Foshee, V. A. (2009). Relationships of adolescents' perceptions of parental and peer behaviors with cigarette and alcohol use in different neighborhood contexts. Journal of Youth and Adolescence, 38(10), 1388-98. Retrieved from https://search.proquest.com/docview/20 4524857

Commons, M. L. (2007). Introduction to the model of hierarchical complexity. Behavioral Development Bulletin, 13: 1-6. https://doi.org/10.1037/h0100493

Cook, E. C., Buehler, C., \& Henson, R. (2009). Parents and peers as social influences to deter antisocial behavior. Journal of Youth and Adolescence, 38(9): 1240-52. https://doi.org/10.1007/s10964-0089348-x

Cooper, M. L., Wood, P. K., Orcutt, H. K., \& Albino, A. (2003). Personality and the predisposition to engage in risky or problem behaviors during adolescence. Journal of Personality and Social Psychology, 84(2): 390-410. https://doi.org/10.1037/00223514.84.2.390

Creswell, J.W. (2016). Qualitative inquiry and research design: choosing among five approaches 2nd edition. California: Sage Publication, Inc.

Crone, E.A., \& Dahl, R.E. (2012). Understanding adolescence as a period of social-affective engagement and goal flexibility. Nature Reviews Neuroscience, 13: 636-650. https://doi.org/10.1038/nrn3313.

Dezfouli, A., \& Balleine, B. W. (2013). Actions, action sequences and habits: evidence that goal-directed and habitual action control are hierarchically organized. Plos Computational Biology, 9(12): 1-14. https://doi.org/10.1371/journal.pcbi.100 3364

Eraslan, M., \& Caliskan, G. (2014). The study of decision making style of university students who do sports. European Scientific Journal 10(8): 15-23. ISSN 18577431.

Fathonah, R. (2016). Analisis terhadap faktor penyebab prostitusi pada anak. Jurnal Poenale, 3(4). 
Feinberg, M. E., Jones, D. E., Kan, M. L., \& Goslin, M. C. (2010). Effects of family foundations on parents and children: 3.5 years after baseline. Journal of Family Psychology, 24(5), 532-542. https://doi.org/10.1037/a0020837.

Felin, T., Koenderink, J., \& Krueger, J. I. (2017). Rationality, perception, and the all-seeing eye. Psychonomic Bulletin \& Review, 24(4), 1040-1059. https://doi.org/10.3758/s13423-0161198-z

Fischhoff, B. (2012). Good decision making requires good communication. Drug Safety, 35(11): 983-93. https://doi.org/10.2165/11636170000000000-00000.

Gardner, M., \& Steinberg, L. (2005). Peer influence on risk taking, risk preference, and risky decision making in adolescence and adulthood: an experimental study. Developmental Psychology, 41(4): 625-635. https://doi.org/10.1037/00121649.41.4.625

Gault-Sherman, M. (2012). It's a two-way street: the bidirectional relationship between parenting and delinquency. Journal of Youth and Adolescence, 41(2): 121-45. https://doi.org/10.1007/s10964-0119656-4.

Haidt, J. (2012). The righteous mind: Why good people are divided by politics and religion. Vintage.

Hansen, L. O., Tinney, B., Asomugha, C. N., Barron, J. L., Rao, M., Curry, L. A., Rosenthal, M. S. (2014). "You get caught up": youth decision-making and violence. Journal of Primary Prevention, 35(1), 21-31. https://doi.org/10.1007/s10935-0130328-x

Harsanti, I., \& Verasari, D. G. (2013). Kenakalan pada remaja yang mengalami perceraian orang tua. Prosiding PESAT, 5.

Heidmets, L., Samm, A., Sisask, M., Kõlves, K., Aasvee, K., \& Varnik, A. (2010). Sexual behavior, depressive feelings, and suicidality among estonian school children aged 13 to 15 years. Crisis: The Journal of Crisis Intervention and Suicide Prevention, 31(3), 128-136. https://doi.org/10.1027/02275910/a000011.

Henson, J. M., Carey, M. P., Carey, K. B., \& Maisto, S. A. (2006). Associations among health behaviors and time perspective in young adults: Model testing with boot-strapping replication. Journal of Behavioral Medicine, 29(2), 127-37. https://doi.org/10.1007/s10865-0059027-2

Hsieh, H. F., \& Shannon, S. E. (2005). Three approaches to qualitative content analysis. Qualitative health research, 15(9), 12771288. https://doi.org/10.1177/1049732305276 687

Hunt, G., \& Chamberland, L. (2006). Is sex work? Re-assessing feminist debates about sex, work, and money. Labour / Le Travail 58:203-216.

Inciardi, J. A. (1995). Crack, Crack House Sex, and HIV Risk. Archives of Sexual Behavior, 24(3): 249-69. https://doi.org/10.1007/bf01541599

Jaccard, J., Blanton, H., \& Dodge, T. (2005). Peer Influences on risk behavior: an analysis of the effects of a close friend. Developmental Psychology, 41(1): 135-147. https://doi.org/10.1037/00121649.41.1.135

Jain, L. C. \& Lim, C. P. (2010). Handbook on decision making vol 1: techniques and applications. Verlag Berlin Heidelberg: Springer. e-ISBN 978-3-642-13639-9.

Janet, M. W. (2002). Commercial sex work or ukuphanda? sex-for-money exchange in soweto and hammanskraal area, South Africa. Culture, Medicine and Psychiatry, 26(3): 339-70. https://doi.org/10.1023/A:10212919220 26.

Jeon, K .C., \& Goodson, P. (2015). Alcohol and sex: the influence of friendship networks on cooccurring risky health behaviors of U.S. adolescents. International Journal of Adolescence and Youth, 21(4): 499-512. https://doi.org/10.1080/02673843.2015. 1110954

Jessor, R., \& Turbin, M. S. (2014). Parsing protection and risk for problem behavior versus pro-social behavior among US and Chinese adolescents. Journal of Youth Adolescence, 43:1037-1051. https://doi.org/10.1007/s10964-0140130-y.

Jonsson, L. S., Svedin, C. G., \& Hydén, M. (2014). "Without the internet, I never would have sold sex": Young women selling sex online. Cyberpsychology: Journal of Psychosocial Research on Cyberspace, 8(1), article 4. https://doi.org/10.5817/CP2014-1-4.

Jung, M. (2012). Sexual, behavioral, and social characteristics of female sex workers and their risk of sexually transmitted infections: in South Korea. Sexuality and Disability, 
https://doi.org/10.1007/s11195-012-

9261-9.

Kaestle, C. E. (2012). Selling and buying sex: a longitudinal study of risk and protective factors in adolescence. Prevention Science, 13(3): 314-322. https://doi.org/10.1007/s11121-0110268-8.

Kangiwa, A. G. (2015). The socio-economic factors and effects of prostitution in Nigeria. European Journal of Research in Social Sciences, 3(5), 70-83 http://www.idpublications.org/wpcontent/uploads/2015/05/

Kaplan, D. L., Jones, E. J., Olson, E. C., \& YunzalButler, C. B. (2013). Early age of first sex and health risk in an urban adolescent population. Journal of School Health 83(5), 350-356. https://doi.org/10.1111/josh.12038.

Keijsers, L., \& Poulin, F. (2013). Developmental changes in parent-child communication throughout adolescence. Developmental Psychology, 49(12), 2301-2308. https://doi.org/10.1037/a0032217

Lutya, T. M. (2010). Lifestyles and routine activities of South African teenagers at risk of being trafficked for involuntary prostitution. Journal of Child and Adolescent Mental Health 22(2): 91-110. https://doi.org/10.2989/17280583. 2010.528578.

Malakooti, B. (2012). Decision making process: typology, intelligence, and optimization. Journal of Intelligeecnt Manufacturing, 23(3): 733-746. https://doi.org/10.1007/s10845-0100424-1

Matswetu, V. S. \& Bhana, D. (2018). Humhandara and hujaya: Virginity, culture, and gender inequalities among adolescents in Zimbabwe. Special Collection Reproductive Health in Sub-Saharan Africa, 1-11.

https://doi.org/10.1177/2158244019859 951

Matzler, K., Uzelac, B., \& Bauer, F. (2014). Intuition's value for organizational innovativeness and why managers still refrain from using it. Management Decision, 52(3), 526-539. https://doi.org/10.1108/MD-08-20130404.

McFall, J. P. (2015). Directions toward a metaprocess model of decision making: cognitive and behavioral models of change. Behavioral Development Bulletin, 20(1):

32-44. https://doi.org/10.1037/h0101038
McGue, M., Elkins, I., Walden, B., \& Iacono, W. G. (2005). Perceptions of the parentadolescent relationship: A longitudinal investigation. Developmental Psychology, 41(6), 971-984. https://doi.org/10.1037/00121649.41.6.971

McNeal, B. A., Walker, J. T. (2016). Parental effects on the exchange of sex for drugs or money in adolescents. American Journal of Criminal Justice, 41: 710-731. https://doi.org/10.1007/s12103-0159313-7.

Modecki, K. L. (2008). Addressing gaps in the maturity of judgment literature: age differences and delinquency. Law and Human Behavior, 32(1), 78-91. https://doi.org/10.1007/s10979-0079087-7

Peng, Y. (2005). "Of course they claim they were coerced": On voluntary prostitution, contingent consent, and the modified whore stigma. Journal of International Women's Studies, 7(2), 17-35. Available at: https://vc.bridgew.edu/jiws/vol7/iss2/2

Rosen, E., \& Venkatesh, S. A. (2008). A "perversion" of choice. Journal of Contemporary Ethnography, 37(4), 417441. https://doi.org/10.1177/0891241607309 879

Sanders, T., O'Neill, M., \& Pitcher. J. (2017). Prostitution: Sex Work, Policy \& Politics 2nd edition. California: Sage Publication, Inc.

Schlegel, A. (1991). Status, property, and the value on virginity. American Ethnologist, 18(4),

719-734. https://doi.org/10.1525/ae.1991.18.4.02a 00050

Shulman, E. P \& Cauffman, E. (2014). Deciding in the dark: age differences in intuitive risk judgment. Developmental Psychology 50(1), 167-177. https://doi.org/10.1037/a0032778

Simon, H.A. \& Associates. (1986). Decision making and problem solving. Research Briefings 1986: Report of the Research by the National Academy of Sciences. Diunduh dari http://www.monitor2manage.com.au/use rdata/downloads

Sinacore, A. L., Jaghori, B., \& Rezazadeh, S. M. (2015). Female university students working in the sex trade: a narrative analysis. Canadian Journal of Counselling and Psychotherapy (Online), 49(1), 40-56. https://cjcrcc.ucalgary.ca/article/view/60991 
Stanton, B., M.D., Li, X., Pack, R., Cottrell, L., Harris, C., \& Burns, J. M. (2002). Longitudinal influence of perceptions of peer and parental factors on african american adolescent risk involvement. Journal of Urban Health, 79(4), 536-48. https://doi.org/10.1093/jurban/ 79.4.536.

Suhardjo, K., \& Irwanto. (2018) Tumbuh bagai ilalang. Jakarta: Penerbit Universitas Katolik Indonesia Atma Jaya.

Suprapto, H. \& Martujdi, T. (Juni 9, 2013). Siswa SMP kepergok jual teman ke lelaki hidung belang. VIVANews. Diunduh dari http://nasional.news.viva.co.id/news/rea d/419393

Terav, T. \& Keltikangas-Jarvinen, L. (1998). Social decision-making strategies among finnish and estonian adolescents. The Journal of Social Psychology, 138(3), 381-391. https://doi.org/10.1080/0022454980960 0390

Thorlindsson, T., \& Bernburg, J. G. (2006). Peer groups and substance use: examining the direct and interactive effect of leisure activity. Adolescence, 41(162), 321-39.

Tucker, J. S., Edelen, M. O., Ellickson, P. L., \& Klein, D. J. (2011). Running away from home: a longitudinal study of adolescent risk factors and young adult outcomes. Journal of Youth and Adolescence, 40(5): 507-18. https://doi.org/10.1007/s10964-0109571-0

UNODC. (2016). Global report on trafficking in persons 2016. New York: United Nations Publication. Diunduh dari http://www.unodc.org/documents

Vanassche, S., Sodermans, A. K., Matthijs, K., \& Swicegood, G. (2014). The effects of family type, family relationships and parental role models on delinquency and alcohol use among flemish adolescents. Journal of Child and Family Studies, 23(1), 128-143. https://doi.org/10.1007/s10826-0129699-5

Vasilenko, S. A., Ram, N., \& Lefkowitz, E. S. (2011). Body image and first sexual intercourse in late adolescence. Journal of Adolescence 34:
327-335.

https://doi.org/10.1016/j.adolescence. 2010.04 .005$.

Wills, T. A., Gibbons, F. X., Gerrard, M., Murry V. M., \& Brody, G. H. (2003). Family communication and religiosity related to substance use and sexual behavior in early adolescence: a test for pathways through self-control and prototype perceptions. Psychology of Addictive Behaviors 17(4): 312-323. https://doi.org/10.1037/0893164X.17.4.312.

Wilson, H. W., \& Widom, C. S. (2008). An examination of risky sexual behavior and HIV in victims of child abuse and neglect: a 30-year follow-up. Health Psychology, 27(2): 149-158. https://doi.org/10.1037/02786133.27.2.149.

Wolak, J. (2009). Research findings in the united states about sexual exploitation via virtual interactions. Dalam ECPAT Internasional. compendium of articles: research findings on child abuse images and sexual exploitation of children online. Bangkok, Thailand: ECPAT Internasional

Wolff, J. M. (2012). Adolescent decision making and risk behavior: a neurobiological approach. A Dissertation. Lincoln, Nebraska: University of Nebraska. https://search.proquest.com/ docview/1010793109/23BBC808ADDF4 DF9PQ/

Yin, R. K. (2014). Case study research: design and methods, 3rd edition. California: Sage Publication, Inc.

Zeglin, J. R. (2014). Participation in prostitution: associated outcomes within familial relationships. Sexuality Research and Social Policy 11: 50-62. https://doi.org/10.1007/s13178-0130143-4.

Zuckerman, M., \& Kuhlman, D. M. (2000). Personality and risk-taking: common biosocial factor. Journal of Personality, 68(6): 999-1029. https://doi.org/10.1111/14676494.00124 


\section{Lampiran A. Tabel Verbatim pada Masing-masing Tahap Pengambilan Keputusan}

\begin{tabular}{|c|c|c|}
\hline \multicolumn{2}{|r|}{ Tahap } & Verbatim \\
\hline 1) & $\begin{array}{l}\text { Mengalami permasalahan } \\
\text { di dalam keluarga }\end{array}$ & $\begin{array}{l}\text { "Sering, dilempar pake remote, pernah kan waktu itu masih } \\
\text { sekolah, nah siangnya udah ngga mau sekolah, dibanjur. "kamu } \\
\text { sekolah gini-gini-gini, mau jadi apa kamu?" Terakhir Eva dibanjur } \\
\text { sama kranjang, pake kranjang obat. Abis itu Eva kabur, berapa } \\
\text { bulan." (E.57) }\end{array}$ \\
\hline & & $\begin{array}{l}\text { "Dari dulu aku pengen banget deket sama kakak perempuan, } \\
\text { cuman gak tau gak bisa. Pas balik lagi ke Bandung aku pikir } \\
\text { suasananya bakal berbeda, taunya sama aja. Justru mah aku gak } \\
\text { keperhatiin aku mah" (A.82). }\end{array}$ \\
\hline 2) & $\begin{array}{l}\text { Mencari dukungan sosial } \\
\text { dari lingkungan teman }\end{array}$ & $\begin{array}{l}\text { "Kan aku diem kabur dua minggu. Aku makan sama anak anak. } \\
\text { Aku dulu ditolongin sama mereka. Masa aku tidak bisa nolongin } \\
\text { mereka kalau lagi susah gitu. Saling nolong. Kalau disaat si teteh } \\
\text { itu punya uang dia yang suka nraktir aku. Tapi saat aku punya } \\
\text { uang ya lewat gitu." (E.161) }\end{array}$ \\
\hline & & $\begin{array}{l}\text { "Jadi kan temen aku udah pada ngekos. pengenya mah kayak } \\
\text { ngeriung, main. senang-senang gitu." (CH.39) }\end{array}$ \\
\hline 3) & $\begin{array}{l}\text { Terpapar dan terlibat } \\
\text { dalam perilaku kenakalan } \\
\text { remaja }\end{array}$ & $\begin{array}{l}\text { "Nakal. Jadi bandel jarang nurut sama orangtua... Cuma } \\
\text { semenjak masuk SMP. Pegaulan itu. Si mama teh gak suka. Jadi } \\
\text { drastis biasanya di rumah sekarang keliaran wae." (CH.60; CH. 61) }\end{array}$ \\
\hline & & $\begin{array}{l}\text { "Kita nongkrong aja, biasanya kita nongkrong aja disitu sambil } \\
\text { ngerokok. Terus karoke. Ada minuman alkohol, ada obat-obatan } \\
\text { ada ganja dilinting, dulu masih suka ganja, diusir dari rumah, } \\
\text { dilempar pake helm sama mamih... } 3 \text { bulan kabur dari rumah terus } \\
\text { pernah setahun gak. Paling pulang cuma ngasih rapot, pulang } \\
\text { sama anak geng motor, pakai baju geng semua. Udah berani } \\
\text { ngelawan aku, kelas } 3 \text { SMP. (C.9; C.150) }\end{array}$ \\
\hline
\end{tabular}
4) Meninggalkan rumah dan dituntut untuk hidup mandiri

"Uang, karena cari uang... Cari uang aja si, cari uang cari kesenangan udah... Seneng bisa hura-hura, bisa happy, ya bisa lepasin semua beban, duit dapet." (E.415)

"Ke salon setiap hari. Soalnya cewek emang sukanya yang kaya gitu kan, ke salon terus perawatan, disuruh dandan, disuruh milih baju, disuruh beli sepatu". (A.218)
5) Terpapar dunia prostitusi
"Kenal sama temen, karaoke tau duit dari situ baru tau duit... Ada mamihnya yang nawarin. Itu aku kelas 1 SMA terus sampai kelas 2 SMA keburu hamil (dengan pacar)". (V.40; V.42)

"Ada temenku bilang, diambil perawan gratis mending dibayar katanya gitu.Ya udah terus ikut BO, booking order aja" (N.22)

6) Terlibat prostitusi
"Akhirnya pacaran eh ya udah dapet V langsung dia ninggalin. Eh gak tau sekarang kemana, aku gak mau kenal lagi sama dia... Uuuh nangis seminggu, terus gak mau megang Hp lagi. Nangis dirumah. Makan juga susah, sampai turun badan 3 kilo (kilogram)." (N.16)

"Ya enggak gimana, mikirnya kan udah enggak perawan itu ya. Sekarang ibaratin kalau misalnya cuma dapat segitukan lumayan 
lima ratus buat seumuran saya dulu bisa beli tas, beli baju, bisa main, bisa minum sama anak-anak, kan." (CH.160)

"Udahnya aku pengen kayak gini (hidup senang), aku kan temennya juga kayak gini-gini juga (terlibat prostitusi). Jadi ya nyaman aja di dunia kayak gini. Lebih nyaman kayak gini". (E.390)

7) Menyesali perbuatannya

"Menyesal sih. Kenapa dulu aku kenal sama dunia kaya gini. Jadi benar kata orang kalau lingkaran setan itu benar. Muter lagi muter lagi ke situ gitu. Kita mencoba berhenti tapi tetap saja kembali kedunia itu. Kecuali kalau kita sudah punya penyakit atau gimana gitu." (CH.344).

"Kadang sekarang mikir takut ngebohongin terus sama orang tua dosanya itu. Terus juga kalau kerja kaya gini dosanya gimana ya sampai nangis lah ya.... Kalau nangis mah kalau lagi kumpulkumpul bareng di sini gitu, kadang sampai nangis." (N.49; N.90). 